UDC 376.37

DOI: $10.23951 / 2782-2575-2021-1-56-63$

\title{
SPEECH DISORDERS OF GENETIC ORIGIN IN TEACHING PRACTICE*
}

\section{I.V. Rudin}

\section{Tomsk State Pedagogical University, Tomsk, Russian Federation}

In recent years, there has been a significant increase in children with various speech disorders. Also, identifying the factors causing these disorders early and providing proper support is increasingly important. If the steps to correct such speech disorders are not taken quickly, secondary issues, such as communication, socialization, and educational problems, are observed. Training and corrective measures should be carried out while considering both the individual's psychological and physiological characteristics. Identifying the cause and symptoms of a speech disorder plays an important role when developing a plan for a child's education, upbringing, and development. These measures are crucial to providing the most suitable help to children with such disorders. The signs identified during diagnosis and those revealing the causes of the speech disorders are vital for outlining a pathogenetic description of the disorder and prescribing a set of corrective measures. Speech disorders indicate the intactness of a large part of the central nervous system, including motor and sensory areas. Moreover, they have diagnostic applications in cases of organic brain damage, malfunctions in the development of the nervous system, and mental retardation of various origins. The pedagogical process must include a full examination, as well as the proper combined support by speech disorder specialists. It is possible to carry out differential diagnoses of speech function disorders using the results of genetic studies and prepare correctional programs tailored to the identified disorders.

Keywords: speech disorders, early diagnosis, genetic syndromes, correction of speech disorders.

In recent years, a distinctive feature of Russian education is a significant increase in the number of children (at both preschool and later stages) with speech disorders of varying severity. Inclusive education provides an opportunity for children with speech disorders to adapt and develop in an educational setting. Human speech, being an integrative mental function $[1,2]$, makes socialization possible and can also reveal information about the development of certain areas of the brain, for example, the motor and sensory centers [3]. Impairment of various areas of the central nervous system can be linked $[4,5]$ to speech disorders, even if these centers are seemingly unrelated to speech. Therefore, the idea that speech can be used for the early diagnosis of disorders of the central nervous system, including screening [6], seems quite reasonable. In addition, early diagnosis provides an opportunity for corrective work earlier on. However, there is a problem of diagnostic differentiation of speech disorders, which, among other things, is reflected in the fact that until now, there has been no single generally recognized classification, which leads to diagnostic issues and a decrease in the predictive value of detected speech disorders $[7,8]$.

This problem is especially relevant in identifying childhood speech disorders [9]. This is explained by both obvious factors, in particular, the child's lack of developed speech before

\footnotetext{
* Original Russian language version of the article: Rudin I.V. Pedagogicheskie osobennosti korrektsii rechevykh rasstroystv, vyzvannykh geneticheskimi sindromami [Pedagogical Particularities in Correction of Speech Disorders Caused by Genetic Syndromes]. Nauchnopedagogicheskoye obozreniye - Pedagogical Review. 2019;6:31-24. DOI: 10.23951/2307-6127-2019-6-31-42
} 
the onset of the disorder, making it difficult to perform a comparative analysis that is possible in the case of an adult patient, and non-obvious - the lack of strict diagnostic criteria due to the presence of different approaches to the classification of speech disorders [10] and multiple factors affecting the vector of ontogenetic development of children, including their speech function, when an adequate assessment of mental functions is complex due to their objective age-related infancy [11]. At the same time, the organization of correctional and pedagogical work should be based on the psychophysiological characteristics of a child obtained during the diagnostic study.

In such conditions, the search for diagnostic markers of the speech disorder etiology becomes relevant for describing an adequate pathogenetic picture of a disorder and determining the grounds for developing correctional programs.

It has been shown that speech function disorder can have a diagnostic value as an early symptom in such conditions as organic brain damage [12], complex disorders of the nervous system development [3], and mental retardation [13-15].

Etiologically, disorders of speech function can be congenital [16-18], acquired [12], or have a mixed nature, as in the case of the Landau-Kleffner syndrome [19], in which both education and the genetic components take place [20].

Suppose, in the case of acquired speech disorders, we can trace the cause-and-effect relations between the etiological factor and the subsequent impairment of speech function, so in that case, the symptomatology of genetic syndromes associated with speech impairment can appear without visible dependence on environmental factors, or there is a regression of the normative function, as in the case of Retta syndrome [21].

Therefore, the idea of the etiology and symptomatology of genetic syndromes has gained greater importance in the early differential diagnosis of speech disorders [22] and has prognostic value in terms of developing adequate individual correctional programs for impaired speech functions and building an individual educational plan for a student. Let us look closely at several genetic syndromes that cause, among other things, delayed speech development.

Angelman syndrome. The etiological factor of Angelman syndrome is an abnormality in the genome of the 15q11.2-q13, 15 chromosome region where several million nucleobase pairs are in the deletion, or there is a mutation of this DNA fragment [17].

In the case of maternal chromosome damage, Angelman syndrome develops, and if the damage is paternal, then Prader-Willi syndrome develops. In addition to symptoms of general underdevelopment and reduced weight gain, convulsive syndrome, tremors, strabism, sleep disturbance, and delayed development of general motor skills can be observed. Children with Angelman syndrome are characterized by a profound delay in speech development in sensory and motor components [23]. The development of such behavioral disorders also characterizes them as attention deficit hyperactivity disorder [24]. At the same time, the non-verbal forms of communication with an apparent dissociation between speech impairment and other expressive forms are possible [25].

Prader-Willi syndrome. The cause of Prader-Willi syndrome is the 15q11.2-q13 region deletion of the fifteenth chromosome, which is inherited from the father. In rare cases, inheritance from the mother is possible. As a rule, the manifestation of the disease is sporadic [17].

As for symptoms, Prader-Willi syndrome manifests itself in low muscle tone, reduced growth, scoliosis, impaired coordination of movements, hypogonadism, strabismus, increased drowsiness, a tendency towards overeating, and obesity [26]. Violation of communicative functions is expressed in fine motor skills delay and a language development delay. Passive vocabulary prevails over an active one. It has been shown that this disorder can be detected at an early age 
based on impairment of spontaneous movements after the 11th week of development and canonical babbling after the 27th week of life [22].

The quality of children's life with Angelman and Prader-Willi syndrome is significantly reduced, which leads to an even more significant deepening of the speech function defect [27].

Rett syndrome. As a developmental nervous system disorder [16], Rett syndrome is manifested by symptoms of regression of cognitive and motor functions, expressed in impaired locomotion, loss of purposeful arm movements (arm twisting), and speech skills. Previously, it was believed that the disease occurs exclusively in females, but the recent cases of Rett syndrome have also been described in boys [28, 29].

Rett syndrome is characterized by the normal development of the newborn between 6-18 months, after which regression of all central nervous system functions that had developed occurs, including speech that can be aggravated up to mutism [30, 31].

Ultimately, the complex of mental and communicative disorders resembles Kanner's syndrome with signs of oligophrenia [32, 33]. Etiologically, the disease develops due to a mutation in the MECP2 gene located on the X chromosome [34, 35].

Smith-Magenis syndrome. Children with Smith-Magenis syndrome have peculiar facial features: brachycephaly, broad flat face, wide nose bridge, protruding forehead, fused eyebrows, and a tent-shaped upper lip. The following features are distinctive: delayed development, muscle tone reduction, congenital malformations of the cardiovascular system, hearing impairment, scoliosis, obesity, and convulsive syndrome [36]. The disease is caused by sporadic deletion of the $17 \mathrm{p} 11.2$ region, which contains the RAI1 gene [18].

The syndrome is accompanied by behavioral disorder and sleep disorder that appear in the second or third year of life. The behavior is characterized by prolonged tantrums, hyperactivity, impulsion, aggressiveness. Emotional excitement [37] is shown through stereotyped movements (shaking hands). Children with Smith-Magenis syndrome are prone to a self-destructive behavior [38]. There is a moderate degree of mental retardation with a general decrease in cognitive functions. In most cases, such children are diagnosed with an autism spectrum disorder. Speech delay, in this case, is more pronounced due to the motor component [37, 39].

Potocki-Lupski syndrome. It is caused by a duplication of the chromosome 17 genome region, localized in region 17p11.2. As in Smith-Magenis syndrome, the RAI1 gene may be involved, but in the Pototski-Lupski syndrome, this gene is duplicated [40, 41]. Symptoms are similar to that of Smith-Magenis syndrome but in a more mild form [42]. Motor activity is restricted. Behavioral disorders are also characterized by hyperactivity, self-destructive behavior, and aggressiveness. Defects in communication are determined by speech stereotypes, verbal stereotypy, abnormalities in intonation, and prosody [43, 44].

Fragile $\mathrm{X}$ syndrome is a genetic syndrome resulting from excessive repetition of the CHG trinucleotide in the FMR1 gene region on the X chromosome [45]. In infancy, it is manifested by a decrease in the frequency of gestural movements [46] and impaired babbling [47]. The subsequent speech is fast and confused and characterized by echolalia and perseveration.

The face has a distinguished appearance: flattened chin, ears that are protruding, and low-set. The iris is light. The skin is highly elastic. Motor extrapyramidal disorders are in the form of muscle tone reduction, tremor, and ataxia. Behavior shows irritability, aggressiveness, and a tendency to self-harm $[48,49]$.

Smith-Lemli-Opitz syndrome. The genetic origin of the disease lies in a mutation in the DHCR7 gene. This gene is responsible for producing the enzyme 7-Dehydrocholesterol reductase, which synthesizes cholesterol $[50,51]$. Low cholesterol levels cause symptoms that vary in severity, ranging from mild to fatal. In children with this syndrome, congenital malformations of 
the cardiovascular and excretory systems, mental retardation, growth retardation, anomalies of the facial skeleton and teeth are revealed $[52,51]$, as well as cognitive functions being impaired. Behavioral and speech disorders are similar to those in autism spectrum disorders [53, 54].

Interestingly, many people are carriers of the defective gene, but since the mode of the syndrome inheritance is recessive, a clinically apparent variant is rare [51].

The analysis of the literature data shows that the etiological spectrum of speech function disorders is quite broad and includes not only the maladaptive influence of the environment and the effect of various pathogens on the developing organism but also an extensive group of genetic syndromes, the clinical manifestations of which are associated with speech disorders. Disturbance of ontogeny in the morphological and functional sense in genetic syndromes has a global nature and includes aspects from the motor to the cognitive. In most cases, dysontogenesis also affects the communicative and intellectual spheres.

When forming pedagogical tools for the development of correctional programs for speech disorders caused by genetic syndromes, it is necessary to consider the global character of the function violations of the child's body in such diseases. Correction of the actual speech disorders should be carried out according to the principles generally accepted in speech therapy [55]. At the same time, during correctional work with children having complex combined defects, the following is recommended: the active use of visualization, elements of game therapy, art therapy, bibliotherapy, hug therapy, and other innovative methods and techniques.

At the same time, given the complexity of the disorders characteristic of the above-described syndromes, it is also necessary to develop corrective programs to restore other impaired functions, be it motor, sensory, cognitive, or another type. This task is demanding both in material, legislative and pedagogical terms. When working with such children, it is necessary to use a complex, systemic, and personality-oriented approach based on a particular child's individual, psychophysiological characteristics. It is also necessary to plan corrective measures, taking into account the prognosis of the disease, which may be unfavorable in the case of genetic syndromes.

At the same time, the development of fundamental science may lead to a prognostic reassessment of the speech disorders correction programs in some genetic syndromes. In particular, methods of gene therapy for Rett syndrome are being developed [56-58], which, when introduced into practice, will make it possible to restore the functioning of the patient's genome both at the organismic level and at the level of speech functions.

Speech function disorder, which is essentially integrative, can serve as one of the first symptoms of a developmental disorder and thus attract the attention of specialists to use it as means of early diagnosis and timely correction. In this sense, scientific works devoted to studying the genetic nature of complex speech disorders are relevant.

Thus, the development of fundamental science at its present stage allows, in some cases, to carry out the differential diagnosis of speech disorders using genetic research and develop correction programs considering the diagnosed developmental deviations.

\section{References}

1. Pomberger T., Risueno-Segovia C., Gultekin Y.B., Dohmen D., Hage S.R. Cognitive control of complex motor behavior in marmoset monkeys. Nature Communications, 2019, vol. 10, is. 1, p.3796. URL: https://doi:10.1038/ s41467-019-11714-8 (accessed 1 October 2019).

2. Livezey J.A., Bouchard K.E., Chang E.F. Deep learning as a tool for neural data analysis: Speech classification and cross-frequency coupling in human sensorimotor cortex. PLOS Computational Biology, 2019, vol. 15, is. 9. URL: https:// doi: 10.1371/ journal.pcbi.1007091.eCollection 2019 Sep. (accessed 1 October 2019).

3. Shriberg L.D., Strand E.A., Jakielski K.J., Mabie H.L.Estimates of the prevalence of speech and motor speech disorders in persons with complex neurodevelopmental disorders. Clinical Linguistics and Phonetics, 2019, 
vol. 33, is. 8, pp. 707-736. URL: https:// doi:10.1080/02699206.2019.1595732 (accessed 1 October 2019).

4. Borisov A.E. Aktual'nyye voprosy kompleksnoy reabilitatsii pri detskom tserebralnom paraliche [Currant issues in comprehensive aftercare of infantile cerebral palsy]. Vestnik Gosudarstvennogo sotsialno-gumanitarnogo universiteta - Herald of State University of Humanities and Social Sciences, 2018, no. 3 (31), pp. 3-45 (in Russian).

5. Batysheva T.T., Krapivkin A.I., Tsaregorodtsev A.D., Sukhorukov V.S., Tikhonov S.V. Reabilitatsiya detey s porazheniyem tsentral'noy nervnoy sistemy [Rehabilitation of children with the pathology of central nervous system]. Rossiyskiy vestnik perinatologii i pediatrii - Russian Bulletin of perinatology and pediatrics, 2017, vol. 62, no. 6, pp. 7-15 (in Russian).

6. Gentilleau-Lambin P., Nicli J., Richard A.F., Macchi L., Barbeau C., Nguyen S., Medjkane F., Lemaître M.P. Assessment of conversational pragmatics: A screening tool for pragmatic language impairment in a control population of children aged 6-12 years.Archives de Pédiatrie, 2019, vol. 26, is. 4, pp. 214-219. URL: https://doi: 10.1016/j.arcped.2019.03.004 (accessed 2 October 2019).

7. Lopatina L.V. Analiz podkhodov k izucheniyu rechevykh i yazykovykh rasstroystv v rossiyskoy i frantsuzskoy logopedii [Analysis of approaches to the research of speech and language disorders in the Russian and French speech therapy]. Izvestiya Rossiyskogo gosudarstvennogo pedagogicheskogo universiteta im. A. I. GertsenaIzvestia: Herzen University Journal of Humanities and Sciences, 2018, no. 190, pp. 100-107 (in Russian).

8. Diagnostic and Statisticalv Manual of Mental Disorders, Fifth Edition. Arlington, VA, American Psychiatric Association, 2013, $947 \mathrm{p}$.

9. Gribova O.E., Batyayeva S.V.K probleme opredeleniya ponyatiya "tyazhelyye narusheniya rechi”" [On the problem of "severe speech disorders" determination]. Obrazovaniye. Nauka. Innovatsii: Yuzhnoye izmereniye - Education. Science. Innovations: the Southern Dimension, 2015, no. 1 (39), pp. 59-74 (in Russian).

10. Bobylova M.Yu., Braudo T.E., Kazakova M.V., Vinyarskaya I.V. Zaderzhka rechevogo razvitiya u detey: vvedeniye $\mathrm{v}$ terminologiyu [Delayed speech development in children: introduction in terminology]. Russkiy zhurnal detskoy nevrologii - Russian Journal of Russian Neurology, 2017, vol. 12, no. 1, pp. 56-62 (in Russian).

11. Gibadullina A.V. Zakonomernosti razvitiya rechi u detey rannego razvitiya v norme [Patterns of normal speech development in young children]. Mezhdunarodnyy studencheskiy nauchnyy vestnik, 2016, no. 5-2, pp. 182-185 (in Russian).

12. Norman R.S., Shah M.N., Turkstra L.S. Language Comprehension After Mild Traumatic Brain Injury: The Role of Speed. American Journal of Speech-Language Pathology, 2019. URL: https://doi:10.1044/2019_AJSLP-18-0203 [Epub ahead of print] (accessed 1 October 2019).

13. Bryukhovskikh L.A.Osobennosti ponimaniya rechi u detey s umstvennoy otstalostyu [Features of understanding speech in children with mental retardation]. Vestnik Krasnoyarskogo gosudarstvennogo pedagogicheskogo universiteta im. V. P. Astafyeva - The bulletin of KSPU named after V. P. Astafiev, 2009, no. 1, pp. 82-87 (in Russian).

14. Birt L., Griffiths R., Charlesworth G., Higgs P,. Orrell M., Leung P., Poland F. Maintaining Social Connections in Dementia:AQualitativeSynthesis. QualitativeHealthResearch,2019.URL:https://doi:10.1177/1049732319874782 [Epub ahead of print] (accessed 1 October 2019).

15. Reppermund S., Heintze T., Srasuebkul P., Reeve R., Dean K., Smith M., Emerson E., Snoyman P., Baldry E., Dowse L., Szanto T., Sara G., Florio T., Johnson A., Clements M., McKenzie K., Trollor J.Health and wellbeing of people with intellectual disability in New South Wales, Australia: a data linkage cohort. BMJ Open, 2019. URL: https://doi:10.1136/bmjopen-2019-031624 (accessed 2 October 2019).

16. Operto F.F., Mazza R., Pastorino G.M.G., Verrotti A., Coppola G. Epilepsy and genetic in Rett syndrome: A review. Brain and Behavior, 2019, vol. 9, is. 5. URL: https://doi:10.1002/brb3.1250 (accessed 1 October 2019).

17. Fricano-Kugler C., Gordon A., Shin G., Gao K., Nguyen J., Berg J., Starks M., Geschwind D.H. CYFIP1 overexpression increases fear response in mice but does not affect social or repetitive behavioral phenotypes. Molecular Autism, 2019. URL: https://doi:10.1186/s13229-019-0278-0 (accessed 1 October 2019).

18. Pounraja V.K., Girirajan S.Molecular basis for phenotypic similarity of genetic disorders.Genome Med, 2019, vol. 11, is. 1, p. 24. URL: https://doi:10.1186/s13073-019-0641-y (accessed 1 October 2019).

19. Besag F.M.C., Vasey M.J.Social cognition and psychopathology in childhood and adolescence.Epilepsy \& Behavior, 2019. URL: https://doi:10.1016/j.yebeh.2019.03.015 [Epub ahead of print] (accessed 3 October 2019).

20. Lesca G., Møller R.S., Rudolf G., Hirsch E., Hjalgrim H., Szepetowski P. Update on the genetics of the epilepsyaphasia spectrum and role of GRIN2A mutations. Epileptic Disorders, 2019, vol. 1, is. 21, pp. 41-47. URL: https:// doi:10.1684/ epd.2019.1056 (accessed 3 October 2019). 
21. Einspieler C., Marschik P.B. Regression in Rett syndrome: Developmental pathways to its onset. Neuroscience \& Biobehavioral Reviews, 2019. URL: https://doi:10.1016/j.neubiorev.2019.01.028 (accessed 1 October 2019).

22. Pansy J., Barones C., Urlesberger B., Pokorny F.B., Bartl-Pokorny K.D., Verheyen S., Marschik P.B., Einspieler C. Early motor and pre-linguistic verbal development in Prader-Willi syndrome - A case report. Research in Developmental Disabilities, 2019, vol. 88, pp. 16-21. URL: https://doi:10.1016/j.ridd.2019.01.012 (accessed 1 October 2019).

23. Carson R.P., Bird L., Childers A.K., Wheeler F., Duis J. Preserved expressive language as a phenotypic determinant of Mosaic Angelman Syndrome. Molecular Genetics \& Genomic Medicine, 2019, vol. 7, is. 9, p.837. URL: https:// doi:10.1002/mgg3.837.(accessed 1 October 2019).

24. Ostergaard J.R. Do individuals with Angelman syndrome have a maladaptive behavior? American Journal of Medical Genetics Part A, 2019. URL: https://doi:10.1002/ajmg.a.61346 [Epub ahead of print] (accessed 1 October 2019).

25. Pearson E., Wilde L., Heald M., Royston R., Oliver C. Communication in Angelman syndrome: a scoping review. Developmental Medicine \& Child Neurology, 2019, vol. 61, is. 11, pp. 1266-1274. URL: https://doi: 10.1111/ dmcn.14257.Epub 2019 May 10 (accessed 3 October 2019).

26. Bohonowych J., Miller J., McCandless S.E., Strong T.V. The Global Prader-Willi Syndrome Registry: Development, Launch, and Early Demographics. Genes (Basel), 2019, vol. 10, is. 9. URL: https://doi:10.3390/genes10090713 (accessed 3 October 2019).

27. Mao S.J., Shen J., Xu F., Zou C.C. Quality of life in caregivers of young children with Prader-Willi syndrome. World Journal of Pediatrics, 2019. URL: https://doi:10.1007/s12519-019-00311-w [Epub ahead of print] (accessed 1 October 2019).

28. Khan A.A., Kirmani S. Mild presentation of the congenital variant Rett syndrome in a Pakistani male: expanding the phenotype of the forkhead box protein G1 spectrum. Clinical Dysmorphology, 2019. URL: https://doi:10.1097/ MCD.0000000000000302 (accessed 2 October 2019).

29. Inui T., Iwama K., Miyabayashi T., Sato R., Okubo Y., Endo W., Togashi N., Kakisaka Y., Kikuchi A., Mizuguchi T., Kure S., Matsumoto N., Haginoya K. Two males with sick sinus syndrome in a family with $0.6 \mathrm{~kb}$ deletions involving major domains in MECP2. European Journal of Medical Genetics, 2019. URL: https://doi:10.1016/j. ejmg.2019.103769 (accessed 1 October 2019).

30. Brima T., Molholm S., Molloy C.J., Sysoeva O.V., Nicholas E., Djukic A., Freedman E.G., Foxe J.J. Auditory sensory memory span for duration is severely curtailed in females with Rett syndrome. Translational Psychiatry, 2019, vol. 9, is. 1, p.130.URL: https://doi:10.1038/s41398-019-0463-0 (accessed 2 October 2019).

31. Key A.P., Jones D., Peters S.Spoken word processing in Rett syndrome: Evidence from event-related potentials. International Journal of Developmental Neuroscience, 2019, vol. 73, pp. 26-31. URL: https://doi:10.1016/j. ijdevneu. 2019.01.001 (accessed 3 October 2019).

32. Clarkson T., LeBlanc J., DeGregorio G., Vogel-Farley V., Barnes K., Kaufmann W.E., Nelson C.A. Adapting the Mullen Scales of Early Learning for a Standardized Measure of Development in Children With Rett Syndrome. Journal of Intellectual \& Developmental Disability, 2017, vol. 55, is. 6, pp. 419-431.URL:https://doi:10.1352/19349556-55.6.419 (accessed 1 October 2019).

33. Perez Y., Menascu S., Cohen I., Kadir R., Basha O., Shorer Z., Romi H., Meiri G., Rabinski T., Ofir R., YegerLotem E., Birk O.S.RSRC1 mutation affects intellect and behaviour through aberrant splicing and transcription, downregulating IGFBP3. Brain, 2018, vol. 141, is. 4, pp. 961-970.URL: https://doi:10.1093/brain/awy045 (accessed 2 October 2019).

34. Martínez-Rodríguez E., Martín-Sánchez A., Coviello S., Foiani C., Kul E., Stork O., Martínez-García F., Nacher J., Lanuza E., Santos M., Agustín-Pavón C. Lack of MeCP2 leads to region-specific increase of doublecortin in the olfactory system. Brain Structure and Function, 2019, vol. 224, is. 4, pp. 1647-1658. URL: https://doi:10.1007/ s00429-019-01860-6.Epub 2019 Mar 28 (accessed 2 October 2019).

35. Ehrhart F., Coort S.L., Eijssen L., Cirillo E., Smeets E.E., Bahram Sangani N., Evelo C.T., Curfs L.M.G. Integrated analysis of human transcriptome data for Rett syndrome finds a network of involved genes. The World Journal of Biological Psychiatry, 2019, pp. 1-14. URL: https://doi:10.1080/15622975.2019.1593501 [Epub ahead of print] (accessed 1 October 2019).

36. Neira-Fresneda J., Potocki L. Neurodevelopmental Disorders Associated with Abnormal Gene Dosage: SmithMagenis and Potocki-Lupski Syndromes. Journal of Pediatric Genetics, 2015, vol. 4, is. 3.pp. 159-167. URL: https://doi: 10.1055/s-0035-1564443. Epub 2015 Sep 28 (accessed 1 October 2019). 
37. Laje G.L., Morse R., Richter W., Ball J., Pao M., Smith A.C. Autism spectrum features in Smith-Magenis syndrome. American Journal of Medical Genetics Part C, 2010, vol. 154C, is. 4, pp. 456-462. URL: https://doi:10.1002/ ajmg.c.30275 (accessed 3 October 2019).

38. Finucane B., Dirrigl K.H., Simon E.W. Characterization of self-injurious behaviors in children and adults with Smith-Magenis syndrome. American Journal on Mental Retardation, 2001, vol. 106, is. 1, pp. 52-58.

39. Wolters P.L., Gropman A.L., Martin S.C., Smith M.R., Hildenbrand H.L., Brewer C.C., Smith A.C. Neurodevelopment of children under 3 years of age with Smith-Magenis syndrome. Pediatric Neurology, 2009. vol. 41, is. 4. URL: https://doi: 10.1016/j.pediatrneurol.2009.04.015 (accessed 2 October 2019).

40. Bissell S., Wilde L., Richards C., Moss J., Oliver C. The behavioural phenotype of Potocki-Lupski syndrome: a cross-syndrome comparison. Journal of Neurodevelopmental Disorders, 2018, vol. 10, iss.1, p.2.URL: https:// doi:10.1186/s11689-017-9221-x (accessed 2 October 2019).

41.Zhang F., Potocki L., Sampson J.B., Liu P., Sanchez-Valle A., Robbins-Furman P., Navarro A.D., Wheeler P.G., Spence J. E., Brasington C.K., Withers M.A., Lupski J.R. Identification of uncommon recurrent Potocki-Lupski syndrome-associated duplications and the distribution of rearrangement types and mechanisms in PTLS.American Journal of Human Genetics, 2010, vol. 86, is. 3, pp. 462-470.URL: https://doi:10.1016/j.ajhg.2010.02.001. Epub 2010 Feb 25 (accessed 1 October 2019).

42. Sanchez-Valle A., Pierpont M.E., Potocki L. The severe end of the spectrum: Hypoplastic left heart in PotockiLupski syndrome. American Journal of Medical Genetics Part A, 2011, vol. 155A, is. 2, pp. 363-366. URL: https://doi:10.1002/ajmg.a.33844 (accessed 3 October 2019).

43. Soler-Alfonso C., Motil K.J., Turk C.L., Robbins-Furman P., Friedman E.M., Zhang F., Lupski J.R., Fraley J.K., Potocki L. Potocki- Lupski syndrome: a microduplication syndrome associated with oropharyngeal dysphagia and failure to thrive. The Journal of Pediatrics, 2011, vol. 158, is. 4, pp. 655-659. URL: https:// doi:10.1016/j. jpeds.2010.09.062 (accessed 3 October 2019).

44. Treadwell-Deering D.E., Powell M.P., Potocki L. Cognitive and behavioral characterization of the Potocki-Lupski syndrome (duplication 17p11.2). Journal of Developmental and Behavioral Pediatrics, 2010, vol. 31, is. 2, pp. 137-143. URL: https://doi: 10.1097/DBP.0b013e3181cda67e (accessed 1 October 2019).

45. Crawford D.C., Acuña J.M., Sherman S.L. FMR1 and the fragile X syndrome: human genome epidemiology review. Genetics in Medicine, 2001, vol. 3, is. 5, pp. 359-371 (accessed 3 October 2019).

46. Hughes K.R., Hogan A.L., Roberts J.E., Klusek J. Gesture Frequency and Function in Infants With Fragile X Syndrome and Infant Siblings of Children With Autism Spectrum Disorder. Journal of Speech Language and Hearing Research, 2019, vol. 62, is. 7, pp. 2386-2399. URL: https://doi:10.1044/2019_JSLHR-L-17-0491 (accessed 2 October 2019).

47. Hamrick L.R., Seidl A., Tonnsen B.L. Acoustic properties of early vocalizations in infants with fragile X syndrome. Autism Research, 2019. URL: https://doi:10.1002/aur.2176 [Epub ahead of print] (accessed 2 October 2019).

48. Eckert E.M., Dominick K.C., Pedapati E.V., Wink L.K., Shaffer R.C., Andrews H., Choo T.H., Chen C., Kaufmann W.E., Tartaglia N., Berry-Kravis E.M., Erickson C.A. Pharmacologic Interventions for Irritability, Aggression, Agitation and Self- Injurious Behavior in Fragile X Syndrome: An Initial Cross-Sectional Analysis. Journal of Autism and Developmental Disorders, 2019. URL: https://doi:10.1007/s10803-019-04173-z (accessed 2 October 2019).

49. Zafarullah M., Tassone F. Fragile X-Associated Tremor/Ataxia Syndrome (FXTAS). Methods in Molecular Biology, 2019, vol. 1942, pp. 173-189. URL: https://doi:10.1007/978-1-4939-9080-1_15 (accessed 2 October 2019).

50. Rojare C., Opdenakker Y., Laborde A., Nicot R., Mention K., Ferri J. The Smith-Lemli-Opitz syndrome and dentofacial anomalies diagnostic: Case reports and literature review. International Orthodontics, 2019, vol. 17, is. 2, pp. 375-383. URL: https://doi: 10.1016/j.ortho.2019.03.020 (accessed 3 October 2019).

51. Waterham H.R., Hennekam R.C. Mutational spectrum of Smith-Lemli-Opitz syndrome. American Journal of Medical Genetics Part C, 2012, vol. 160C, is. 4, pp. 263-284. URL: https://doi:10.1002/ajmg.c.31346 (accessed 3 October 2019).

52. Donoghue S.E., Pitt J.J., Boneh A., White S.M. Smith-Lemli-Opitz syndrome: clinical and biochemical correlates. Journal of Pediatric Endocrinology and Metabolism, 2018, vol. 31, is. 4, pp. 451-459. URL: https://doi:10.1515/ jpem-2017-0501 (accessed 3 October 2019). 
53. Nowaczyk M.J., Irons M.B. Smith-Lemli-Opitz syndrome: phenotype, natural history, and epidemiology. American Journal of Medical Genetics Part C, 2012, vol. 160C, is. 4, pp. 250-562. URL: https://doi:10.1002/ajmg.c.31343 (accessed 2 October 2019).

54. DeBarber A.E., Eroglu Y., Merkens L.S., Pappu A.S., Steiner R.D. Smith-Lemli-Opitz syndrome. Expert Reviews in Molecular Medicine, 2011, vol. 13. URL: https://doi:10.1017/S146239941100189X (accessed 1 October 2019).

55. Panasenko K.E. Soderzhaniye i napravlennost' deyatel'nosti uchitelya-logopeda po razvitiyu kommunikativnykh navykov u doshkol'nikov s rasstroystvami autisticheskogo spektra [The content and focus of teacher-speech therapist's development of communication skills in preschoollers with autism spectrum disorders]. Sovremennye naukoemkiye tekhnologii - Modern High Technologies, 2018, no. 8, pp. 209-213 (in Russian).

56. Le T.T.H., Tran N.T., Dao T.M.L., Nguyen D.D., Do H.D., Ha T.L., Kühn R., Nguyen T.L., Rajewsky K., Chu V.T. Efficient and Precise CRISPR/Cas9-Mediated MECP2 Modifications in Human-Induced Pluripotent Stem Cells. Frontiers in Genetics, 2019, vol. 10, pp. 625-637. URL: https://doi:10.3389/fgene.2019.00625.ECollection 2019 (accessed 1 October 2019).

57. Gogliotti R.G., Niswender C.M. A Coordinated Attack: Rett Syndrome Therapeutic Development. Trends in Pharmacological Sciences, 2019, vol. 40, is. 4, pp. 233-236. URL: https://doi:10.1016/j.tips.2019.02.007 (accessed 1 October 2019).

58. Banerjee A., Miller M.T., Li K., Sur M., Kaufmann W.E. Towards a better diagnosis and treatment of Rett syndrome: a model synaptic disorder. Brain, 2019, vol. 142, is. 2, pp. 239-248. URL: https://doi: 10.1093/brain/ awy323.(accessed 1 October 2019).

Iliya V. Rudin, Tomsk State Pedagogical University (ul. Kiyevskaya, 60, Tomsk, Russian Federation, 634061).

E-mail: iliawr@yahoo.com 